\title{
Eczacılık fakültelerinde farmakoekonomi eğitimi ve öğrencilerin farmakoekonomi ile ilgili bilgi düzeyleri
}

\author{
Nazlı Şencan ${ }^{1,2}$, Mehtap Kurt² ${ }^{2}$ Çiğdem Kaspar ${ }^{3}$, Albert Wertheimer ${ }^{4}$
}

\section{ÖZET}

AMAÇ: Bu çalışmada Eczacılık Fakültelerinde verilen farmakoekonomi eğitimi incelenmiş ve öğrencilerin farmakoekonomi hakkındaki bilgi düzeylerinin tespit edilmesi amaçlanmıştır. Farmakoekonominin dünyada eczacılık eğitimi programlarındaki yeri ile karşılaştırmalı olarak konunun öneminin ve Türkiye'deki durumun ortaya konulması hedeflenmiştir.

METOD: Araştırmanın amacına uygun olarak İstanbul ve Ankara'da bulunan Eczacılık Fakültelerinin 4. ve 5. sınıf öğrencilerinin farmakoekonomi hakkındaki bilgi düzeylerini tespit etmek amacıyla araştırmacı tarafından hazırlanan anket yöntemi kullanılmıştır.

BULGULAR: Öğrencilere uygulanan anket sonuçları değerlendirildiğinde ise eğitim müfredatında farmakoekonomi dersi yer alan fakültelerin öğrencilerinin konu hakkında diğer fakülte öğrencilerine göre daha çok bilgi sahibi oldukları görülmüştür. Öğrencilerinin \%78'inin farmakoekonomi ile ilgili eğitim alma konusunda istekli oldukları tespit edilmiştir. Farmakoekonomi alanında uzman birini/birilerini tanıyan öğrencilerin bu alanda kariyer yapmayı planladıkları tespit edilmiştir. Öğrencilerin \%18,9'unun farmakoekonomi alanında çalışma yapmayı planlaması bu konudaki eğitim ihtiyacını da gündeme getirmektedir.

SONUÇ: Anket çalışmasına beş eczacılık fakültesinden 970 öğrenci katıımıştır. Toplanan bilgiler ışığında Eczacılık Fakültelerinin ikisinde farmakoekonomi dersinin müfredata yer aldığı, üçünde yer almadığı gözlenmiştir. Bu araştırmada farmakoekonomi biliminin önemi öğrencilerin bakış açısından sorgulanmış olup öğrencilerin \%92,9'u farmakoekonomi biliminin yeterince bilinmediğini bildirmişlerdir. Farmakoekonomi hastaların yaşam kalitesini arttırmada önemli bir hedef olduğu için; eczacıların bu alandaki aktivitelerini arttırmak üzere aksiyonlar alınması gerekmektedir. Eczacılık fakültelerinin müfredatlarına farmakoekonomi dersinin eklenmeli, ardından bu alanda eğitimli uzman sayısını arttırmak amacıyla yüksek lisans ve doktora programlarının açılması gerekliliği göz önünde bulundurulmalıdır.

ANAHTAR KELIMELER: Farmakoekonomi, Sağlık ekonomisi, Eğitim, Eczacılık, Eczacılık eğitimi

\section{GiRiş}

Dünyada hiçbir ülkenin, yurttaşlarına sınırsız sağlık hizmeti sunabilecek sonsuz ekonomik olanakları ve finansal kaynağı bulunmamaktadır. Özellikle gelişmekte olan ülkelerde sağlık için yapılan harcamaların ekonomik kaynaklar ile orantısız biçimde artması, sağlık harcamalarında adil ve akılcı politikaların belirlenmesi ve izlenmesini zorunlu kılmaktadır. Sağlık harcamaları ve sağlık harcama politikalarının daha ayrıntılı olarak araştırılması için disiplinler arası işbirliğinin kaçınılmaz nitelik taşıması, ayrı ve bağımsız bir disiplin olarak "farmakoekonomi" disiplininin doğmasına yol açmıştır (1). Sağlık alanındaki gelişmeler sonucunda sağlık harcamalarının giderek artması ve mevcut kaynağın daha
KURUM

1Yeditepe University Faculty of Pharmacy, Pharmacy management and Social Pharmacy, İstanbul, Türkiye

2Yeditepe Üniversitesi

Eczacılık Fakültesi

Farmakoekonomi ve

Farmakoepidemiyoloji

Araştırmaları Merkezi

(PEPIRC), İstanbul, Türkiye

3Yeditepe Üniversitesi

Tıp Fakültesi, Tıp Bilişimi

Anabilim Dalı, İstanbul,

Türkiye

4Temple University,

Health Economics and

Outcome Research Center,

Philadelphia, ABD

İLETIŞiM

Nazlı Şencan

E-posta:

nazlisencan@yeditepe.edu.tr

Gönderilme:

01.10 .2013

Revizyon:

23.11.2013

Kabul:

02.12.2013 
rasyonel bir biçimde kullanılması zorunluluğu da farmakoekonomiye olan ihtiyacı arttırmaktadir.

İçinde bulunduğumuz yüksek teknoloji çağında bir yandan hastalıkların tedavisi için önemli buluşlara imza atılırken, öte yandan tedavi maliyetleri de yükselmiştir. Bu durum, sağlık hizmeti sunan kişi ve kurumların sorumluluk alanlarını genişletmiştir. Eskiden temel sorumlulukları hastaların tedavi edilmesi olan sağlık hizmeti sunan kişi ve kurumlar, artık hastalar kadar, hasta olmayanları da dikkate almak durumundadırlar (2). Bu nedenle para ödeyen kurum ve kuruluşlar artan maliyetleri minimize etmek üzere çeşitli aksiyonlar almaya çalışmaktadırlar.

Farmakoekonomi, sağlık alanında sunulacak her türlü hizmetin, teknolojinin, girişimin veya ilaç tedavilerinin sonuçlarını değerlendirmeyi ve karşılaştırmayı, bu karşılaştırmadan kamu yararına adil ve akılcı sonuçlar çıkarmayı hedeflemektedir. Bir başka deyişle farmakoekonomi, bir disiplin olarak ekonomiye dair kuramların, araçların ve kavramların sağlık ve sağlık hizmetlerine yönelik olarak kullanılması olarak tanımlanabilir (2). Ekonomi bilimi kıt kaynaklar ile sınırsız ihtiyaçların giderilmesi çabası ile ilgilenmek olarak ele alındığında, farmakoekonomi alt bilimi ilaç ve tedaviye ilişkin sınırsız ihtiyaçlar ile ödeyen kurumun kaynakları arasındaki dengenin değerlendirilme politikası olarak tanımlanabilir.

İlk olarak 1970'li yıllarda batılı ülkelerde gündeme gelen farmakoekonomi politikası giderek önemi artan bir konu olmuştur. Minnesota Üniversitesi'nden McGhan, Rowland ve Bootman farmakoekonominin temel analizlerinden iki tanesi olan maliyet-yarar ve maliyet-etkililik kavramlarını tıp ve eczacılık literatürlerine kazandırmışlardır ve kendi üniversitelerinde farmakoekonomi ile ilgili dersi lisans ve yüksek lisans öğrencileri için eczacılık müfredatına eklemişlerdir (3). Bootman ve ark. 1979'da sofistike farmakokinetik protokoller kullanarak gram-negatif septisemisi olan ağır derecedeki yanık hastalarında aminoglikozit dozajının bireyselleştirilmesinin sonuçlarını değerlendirmek için maliyet-yarar analizinin kullanıldığı ilk eczacılık araştırma makalelerinden birini yayınlamışlardır. Günümüzdeki "farmakoekonomi” terimi, literatürde 1986 yılında, Townsend'in bir sunumunda ilerlemekte olan bu disiplinde araştırma aktivitelerinin geliştirilmesi ihtiyacının vurgulanmasına kadar görülmemiştir (4). Farmakoekonomi, özellikle ABD (Amerika Birleşik Devletleri)'de gerçekleştirilen ilk çalışmalardan sonra Avrupa ülkelerinin bir bölümünde ve Avustralya ile Kanada'da üzerinde yoğun bir biçimde durulan bir kavram haline gelmiştir (5).

Bilgi toplumuna geçilen modern dünyada kazanılmış beceri ve kapasitelere verilen önem ve aynı zamanda yükseköğretimin değeri de süratle artmaktadır. Bu çerçevede gerek eğitimin kalitesi, gerekse sağlık hizmet kalitesinin geliştirilmesi bir arada kazanılmış beceri ve kapasiteler geliştirilmesine hizmet edecek ve bu da ülkelerin kalkınmasına ciddi katkı sağlaması beklenmektedir. Sağlık bilimlerindeki eğitim kalitesinin geliştirilmesinin ülke kalkınmasındaki önemi ayrıcalıklı yere sahiptir. Bu durumda eczacıların eğitim kalitelerinin yüksek tutulması da tıpkı diğer sağlık hizmeti sunucularının eğitiminde olduğu gibi kritik öneme sahiptir (6). Eczacıların eğitim kalitelerini yükseltmek üzere eczacılık öğrencilerine müfredat kapsaminda verilebilecek konulardan biri de farmakoekonomidir.

Dünyada farmakoekonomi alanında donanımlı uzmanlar yetiştirmek üzere pek çok eğitim programı mevcuttur. Kısa kurslar, çalıştaylar, stajlar, lisans dersleri, master ve doktora programları bunlardan bazılarıdır (7). Öğrencilere farmakoekonomiyi öğretmenin en kritik yollarında biri de, bu konuyu üniversitelerde teorik derslerin içerisinde yapılandırılmasıdır (8).

Eczacılık fakültesi öğrencileri mezun olup mesleğe atıldıklarında sağlık sisteminin birer parçası haline gelmektedirler. Eczacıların; hasta bakımında, hastaların sağlık statülerinde ve hasta bakım dağıtım sistemlerinin sağlanmasında farmasötiklerin klinik ve ekonomik etkisini değerlendirebilmeleri gerekmektedir (9). Eczacılar sağlık sistemindeki kıt kaynakları etkili kullanabilmek üzere tedavi maliyetlerini minimize etmek ve hasta yaşam kalitesini arttırmak için ödeyici kurum ve kuruluşlara yardımcı olmak, yani günlük pratiklerinde farmakoekonomiyi uygulamak durumundadırlar. Eczacıların genellikle "ilaç uzmanı" olarak değerlendirildikleri düşünülürse; ilaç tedavisi maliyetlerini ve çıktılarını değerlendirmek için ideal sağlık çalışanı oldukları söylenebilir. Farmakoekonomi alanındaki potansiyel rolü çok önemlidir (10). Bunun için eczacılık fakültesi öğrencilerinin farmakoekonominin temel ilke ve kuralları konusunda bilgi sahibi olmaları gereklidir.

\section{AMAÇ VE METOD}

Bu çalışmada Eczacılık Fakülteleri'nde verilen farmakoekonomi eğitim düzeyinin incelenmesi ve öğrencilerin farmakoekonomi hakkındaki bilgi düzeylerinin tespit edilmesi amaçlanmıştır. Farmakoekonomi konusunun dünyada eczacılık eğitimi programlarındaki yeri ile karşılaştırmalı olarak konunun öneminin ve Türkiye'deki durumun ortaya konulması hedeflenmiştir.

Araştırmada, İstanbul ve Ankara' da bulunan eczacılık fakültesi 4. ve 5. sınıf öğrencilerinin aldıkları farmakoekonomi eğitimi ve farmakoekonomi konusundaki bilgi düzeyleri tespit edilmeye çalışılmıştır. Öğrencilerin bakış açısına ve algısına göre üniversite düzeyinde verilen farmakoekonomi eğitimi konusundaki mevcut durumun ortaya konulması amaçlanmıştır. Bu çalışma Türkiye' deki eczacılık öğrencilerinin farmakoekonomi konusunda aldıkları eğitimi ve bu konudaki bilgi düzeylerini değerlendiren ilk çalışmalardan biri olduğu söylenebilir.

Araştırma Yöntemi: Araştırmada, anket yöntemi kullanılmıştır. Uygulanan anketler araştırmacı tarafından hazırlanmıştır. 2001/2002 eğitim öğretim yılında Avrupa'daki eczacılık öğrencilerinin farmakoekonomi konusundaki bilgi düzeylerini ölçen bir anket çalışması Avrupa Eczacılık Öğrencileri Birliği (EPSA) tarafından yapılmıştır (11). Yine Amerika'da ve Amerika dışındaki ülkelerde Eczacılık Fakültelerinde verilen farmakoekonomi eğitimini değerlendiren yayınlar mevcuttur (12-14). Araştırma sonucunda Türkiye ve Avrupa'daki durum tartışılmaktadır.

Anket Dizaynı: Anket soruları hazırlanırken EPSA tarafından 2001-2002 eğitim öğretim yılında yapılan ve Avrupa'daki eczacılık öğrencilerinin farmakoekonomi hakkındaki bilgi seviyesini ölçen anket çalışmasından yararlanılmıştır. 
Veri Analizi: Anket sonuçları Microsoft Office Excel 2010 kullanılarak elektronik ortama aktarılmış ve veri analizi SPSS Versiyon 16 ile yapılmıştır. Araştırma örneklemini oluşturan bireylerin demografik özelliklerini belirlemek için tanımlayıcı istatistiksel yöntemler (frekans ve yüzde) kullanılmıştır.

Araştırma sonuçlarının test edilmesinde Ki-kare testi, MannWhitney U testi ve Kruskall-Wallis testi kullanılmıştır. Ki-Kare testi, parametrik test varsayımları yerine getirilmediğinde, iki veya daha fazla grubu, sayımla belirtilen değişkenler yönünden karşılaştırmada kullanılan parametrik olmayan istatistik testlerden biridir. Mann-Whitney U testi ise niceliksel ölçekli gözlemleri verilen iki örneklemin aynı dağılımdan gelip gelmediğini incelemek için kullanılan bir parametrik olmayan istatistik testtir. Kruskal-Wallis testi de parametrik olmayan verilere sahip ikiden fazla grubun ölçümlerinin karşılaştırılmasinda kullanılan bir yöntemdir (15). Hesaplamalar yapılırken güven aralığı \%95 olarak seçilmiş; $\mathrm{p}<0.05$ değeri anlamlı olarak kabul edilmiştir.

\section{Araştırmanın evreni ve örneklem seçimi}

Ankara ve İstanbul'daki Eczacılık Fakültesi öğrencileri bu araştırmanın evrenini oluşturmaktadır. Eczacılık eğitiminin ilk üç yılında eğitimin temel bilimler ve temel eczacılık bilimleri üzerine yoğunlaşması nedeniyle, öğrencilerin farmakoekonomi hakkında pek bilgi sahibi olamayacakları varsayımı ile anket 4 . ve 5. sınıf öğrencilerine uygulanmıştır.

Anket çalışmasının uygulandığı Eczacılık Fakülteleri şunlardır:

- $\quad$ Ankara Üniversitesi Eczacılık Fakültesi

- Gazi Üniversitesi Eczacılık Fakültesi

- İstanbul Üniversitesi Eczacılık Fakültesi

- Marmara Üniversitesi Eczacılık Fakültesi

- Yeditepe Üniversitesi Eczacılık Fakültesi

Çalışmanın Yasal Onayı: Çalışma için Yeditepe Üniversitesi Tıp Fakültesi Klinik Araştırmalar Değerlendirme Komitesi tarafından 14.02.2012 tarih ve 163 no.lu yazı ile etik kurul onay1 alınmıştır. Eczacılık Fakültesi dekanlıklarından gerekli izinler alınarak anketler öğrencilere uygulanmıştır. Araştırmacı tarafından fakültelere bizzat gidilerek, anketler öğrencilere ders veya sınav öncesinde sınıflardaki tüm öğrencilere aynı anda uygulanmıştır.

\section{BULGULAR}

20 Şubat 2012 - 08 Haziran 2012 tarihleri arasında araştırma evreninde ve sahasında gerçekleştirilen anket uygulaması sonrasında 970 adet anket toplanmıştır. Anketler Ankara Üniversitesi, Gazi Üniversitesi, İstanbul Üniversitesi, Marmara Üniversitesi ve Yeditepe Üniversitesi öğrencilerine uygulanmıştır. Bu üniversitelerde kayıtlı olan ve ankete katılar öğrenci sayıları Şekil 1'de özetlenmiştir.

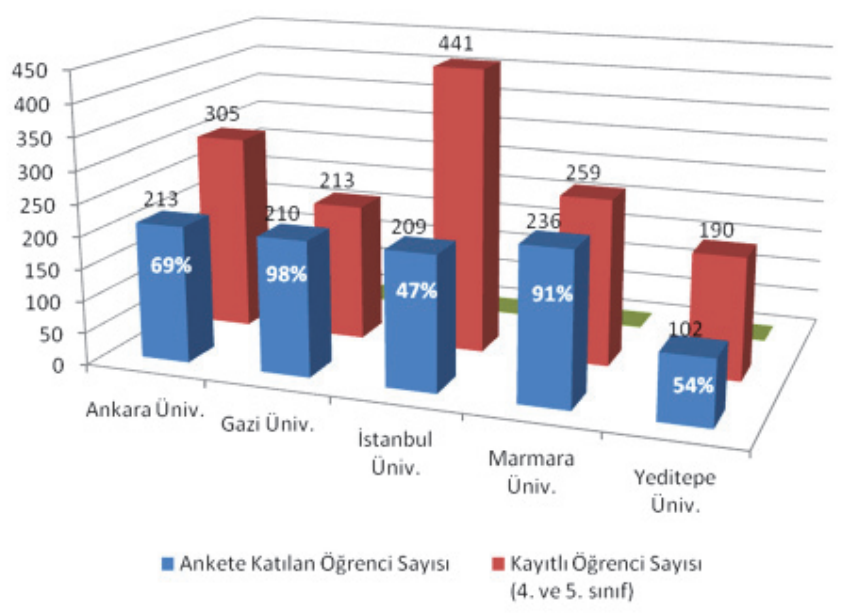

ŞEKiL 1. Ankete katılan öğrenci sayısı

Çalışmaya katılan öğrencilerin cinsiyetleri incelendiğinde; büyük bir bölümünün $(\% 61,3)$ kadın olduğu gözlenmektedir. Bu bulgular, kadınların eczacılık mesleğini daha fazla tercih ettiğini destekler niteliktedir. Katılımcıların \%92,7'sini oluşturan büyük bir çoğunluğun beklendiği üzere 20-25 yaş aralığında olduğu görülmektedir. \%7,3'lük bir öğrenci gurubunun ise ya ikinci kez üniversite okuduğu ya da aftan faydalanarak üniversiteye devam ettiği düşünülebilir.

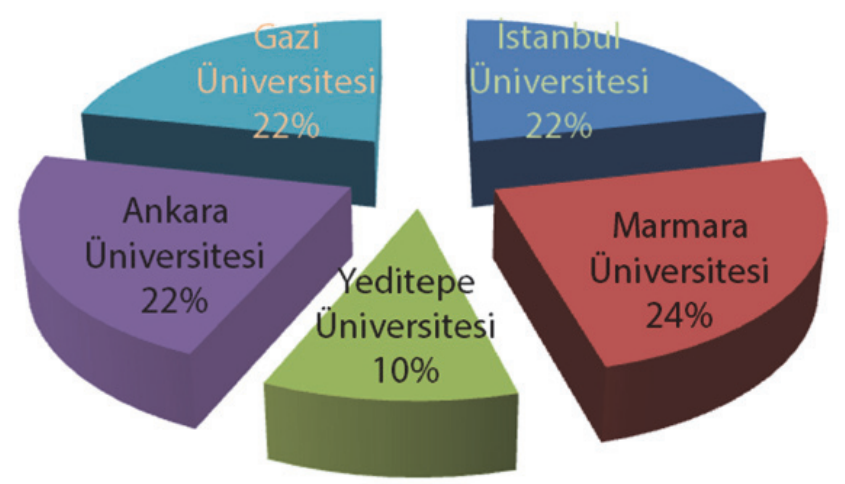

ŞEKiL 2. Üniversite dağııımı

Ankete katılan öğrencilerin yarısının 4. sınıf, diğer yarısının ise 5. sınıf öğrencisi olduğu gözlenmiştir. Ankete katılanların büyük bir çoğunluğu $(\% 68,5)$ mezun olduktan sonra "serbest eczacı" olarak çalışmak istediklerini bildirmişlerdir. "İlaç sektörü"nde çalışmak isteyenler katılımcıların yaklaşık altı da birini $(\% 16,1)$ oluşturmaktadırlar.

\section{Öğrencilerin farmakoekonomi eğitimi ile ilgili görüşleri}

Bu araştırmanın ana amaçlarından biri olan farmakoekonomi konusunun güncel ve gelecekteki müfredatta yer almasına ilişkin sorular ve cevaplarına ilişkin veriler, şekiller ve tablolar aşağıda yer almaktadır.

Katılımcıların büyük bir çoğunluğu (n=692, \%71,3) "farmakoekonomi" konusunun eczacılık eğitimi müfredatında yer almadığını bildirmişlerdir. Eğitim müfredatında farmakoekonomi konusunun yer alma durumu ile ilgili öğrencilere yöneltilen 
soruya ise Yeditepe Üniversitesi öğrencilerinin \%95,1'inin, Gazi Üniversitesi öğrencilerinin \%65,7'sinin bu konunun müfredatta yer aldığ1 yönünde cevap verdiği gözlenmiştir. Gazi Üniversitesi'nden ankete katılan öğrencilerin \%65'i 5. sınıf öğrencisidir ve bu fakültede farmakoekonomi konusu 5. sinif müfredatında yer almadığı bilgisi teyid edilmiştir.

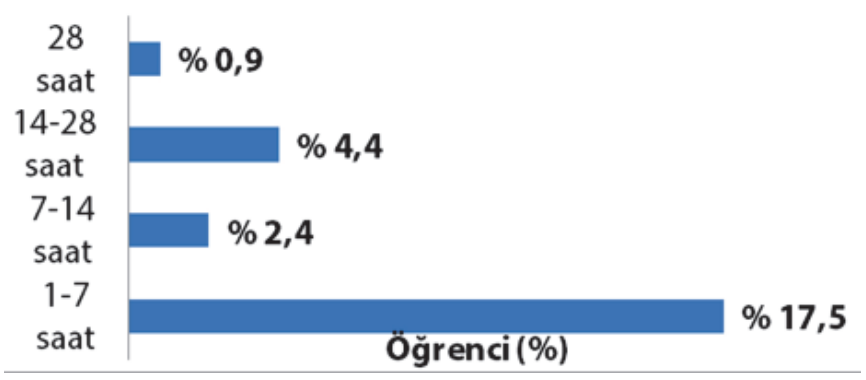

ŞEKiL 3. Farmakoekonomi konusunda alınan eğitimin süresi

Farmakoekonomi konusunun müfredatta yer aldığını bildiren 278 kişiden 132'si (\%47,5), bu dersin “Zorunlu” olduğunu belirtmiştir. Zorunlu veya seçmeli olarak alınan farmakoekonomi konusundaki eğitime ders programında kaç saat ayrıldığı sorulduğunda, lisans ögrrencilerinin en çok $(\% 17,5) 1-7$ saat cevabı verdiği görülmektedir.

Farmakoekonomi eğitimi alan katılımcıların büyük bir çoğunluğunun (\%72) aldıkları bilgileri iş yaşamında kullanabileceklerine inandıklarını bildirmişlerdir $(\mathrm{p}<0,05)$.

\section{Sizce farmakoekonomi konusu lisans eğitimindemüfredatta yer almalı mı?}
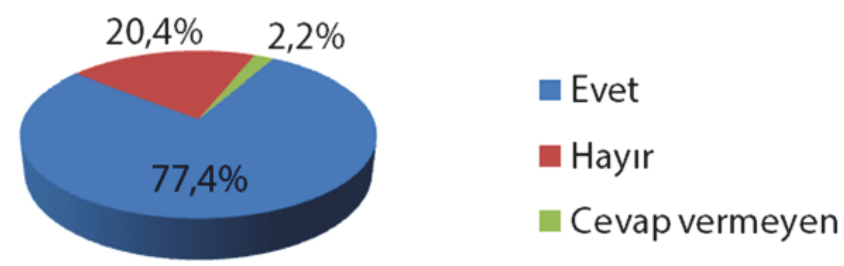

ŞEKiL 4. Farmaekoeokonomi konusunun müfredatta yer alması gerekliliği

Araştırmaya katılan öğrencilerin çok büyük bir çoğunluğunun $(\% 77,4)$ müfredatta farmakoekonomi olması gerektiğine inandıkları anlaşılmıştır.

Katılımcılara "farmakoekonomi" eğitiminin hangi sınıfta alınmasının daha iyi olduğu sorulmuştur. Öğrencilerin büyük bir çoğunluğunun $(\% 32,3) 3$. sınıftan itibaren \%15'inin de 4 . Sınıfta yer alması gerektiğini bildirmişlerdir.

Farmakoekonominin müfredatta yer alması kadar önemli bir konu da, bu eğitimi verebilecek uzman eğitmenlerin varlığıdır. Öğrencilerin bakış açısı ile üniversitelerde konu ile ilgili ders verebilecek uzman kişiler bulunmamaktadır (\%62,2). Tablo 7'de eczacılık fakültelerinde farmakoekonomi konusunda uzman biri olup olmadığına yönelik olarak eczacılık öğrencilerinin görüşlerine yer verilmiştir.
TABLO 1. Fakültelerdeki farmakoekonomi konusunda uzman kişilerin varlığı Fakültenizde spesifik olarak farmakoekonomi konusunda uzman kişi/kişiler var midır?

\begin{tabular}{lcc}
\hline & $\mathbf{n}$ & $\%$ \\
\cline { 2 - 3 } Evet & 237 & 24,4 \\
Hayır & 603 & 62,2 \\
Cevap vermeyen & 130 & 13,4 \\
Toplam & 970 & 100
\end{tabular}

Öğrencilerin lisans sonrası eğitim döneminde farmakoekonomi alanında çalışma yapmayı düşünüp düşünmedikleri de sorgulanmıştır. Eczacılık öğrencilerinin “Lisans sonrası eğitim döneminde farmakoekonomi alanında çalışmalar yapmayı düşünür müsünüz?" sorusuna verdikleri cevaplar değerlendirilmiştir. Öğrencilerin \%20,4'ünün "Evet”, \%77,5'inin ise "Hayır" yanıtı verdiği görülmüştür.

Eczacılık öğrencilerinin mezuniyet sonrası çalışmayı istediği alan ile "Lisans sonrası eğitim döneminde farmakoekonomi alanında çalışmalar yapmayı düşünür müsünüz?” sorusuna verdikleri cevaplar karşılaştırılmıştır. Lisans sonrası eğitim döneminde farmakoekonomi alanında çalışma yapma isteği ile ilgili soruya verilen cevaplar ile öğrencilerin mezun olduklarında çalışmayı düşündükleri eczacılık alanına göre istatistiksel açıdan anlamlı olup olmadığı Ki-kare testi ile incelenmiş ve test sonucunda;

Serbest eczacı olmayı ve ilaç sektöründe kariyer yapmayı düşünen öğrenciler ile bu soruya yanıt veren öğrenciler arasında istatistiksel olarak anlamlı bir fark vardır $(p<0,05)$.

Akademik kariyer yapmayı ve hastane eczacısı olmayı düşünen öğrenciler ile bu soruya yanit veren öğrenciler arasında istatistiksel olarak anlamlı bir fark bulunmamıştır $(p>0,05)$

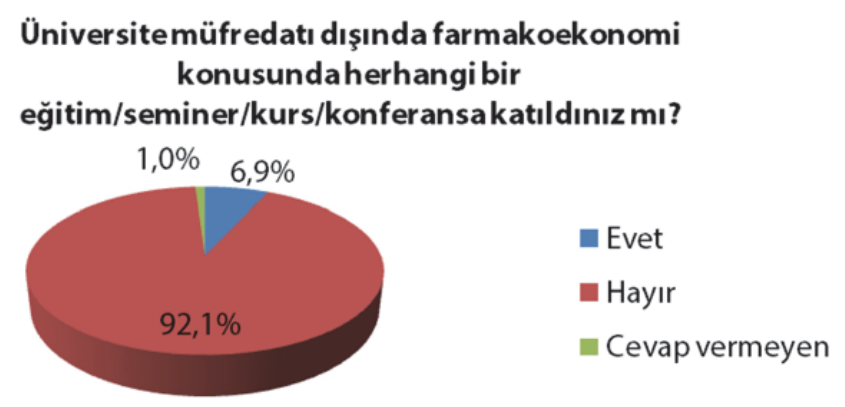

ŞEKiL 5. Farmakoekonomi alanında alınan eğitim/seminer/kurs/konferans

Öğrencilerin farmakoekonomi ile ilgili üniversite müfredatı dışında herhangi bir eğitim/seminer/kurs/konferansa katılıp katılmadıkları bilgisi Şekil 5'de gösterilmektedir. Bu soruya, öğrencilerin \%6,9'unun "Evet", \%92,1'inin ise "Hayır" yanıtı verdiği görülmüştür.

Eczacılık öğrencilerinin farmakoekonominin genel terimleri ile ilgili sorulara verdikleri cevaplar öğrencilerin öğrenim gördüğü okul bilgisi ile karşılaştırılmıştır. Bu karşılaştırmanın sonucunda, öğrencilerin öğrenim gördüğü üniversite ile maliyet analizleri hakkındaki bilgi düzeyleri açısından gözlenen farklılıklar Ki-kare testi ile sınanmış ve istatistiksel olarak anlamlı 
bir fark olduğu bulunmuştur $(\mathrm{p}<0,05)$. Fakültede ders alan öğrencilerirn, maliyet-etkinlik, maliyet-minimizasyonu, maliyetyarar gb analiz yöntemlerini duydukları ve bildikleri söylenebilir.

Katılımcıların \%85,8'i farmakoekonomik değerlendirme çalışmalarının yeni bir tedavi için geri ödeme kararı verirken standart bir araç olarak kullanılabileceğini belirtmiştir. Farmakoekonomi eğitimi veren ve vermeyen fakülteler arasında anlamlı bir farkın saptandığı söylenebilir $(p<0,05)$.

\section{Sizce farmakoekonomik çalışmalar sadece yeni ürünler için karar verirken mi yoksa hali hazırda geri ödenmekte olan ürünler için mi kullanılmalıdır?}
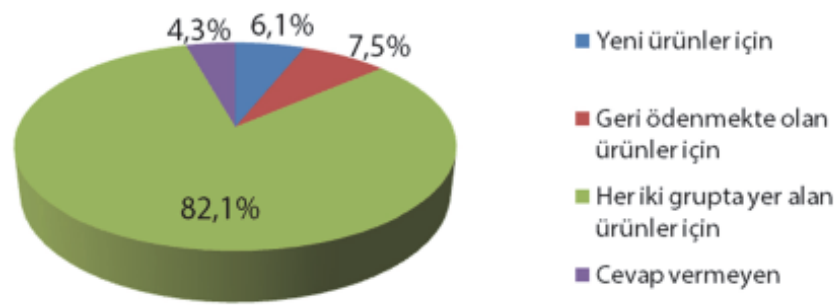

ŞEKiL 6. Farmakoekonomik Çalışmaların Kullanıldığı Ürünler

Şekil 6'da farmakoekonomik çalışmaların sadece yeni ürünler için karar verirken mi yoksa hali hazırda geri ödenmekte olan ürünler için mi kullanıldığı konusunda eczacılık öğrencilerinin görüşlerine yer verilmiştir. Katılımcıların \%82,1'i farmakoekonomik çalışmaların hem hali hazırda geri ödenmekte olan ürünler için hem de yeni ürünler için kullanıldığ1nı belirtmiştir. Farmakoekonomik çalışmaların kullanıldı̆̆ ürünler ile ilgili soruya verilen cevaplar değerlendirildiğinde; fakülteler arası homojen bir dağılım olduğundan bahsedilebilir $(\mathrm{p}>0,05)$.

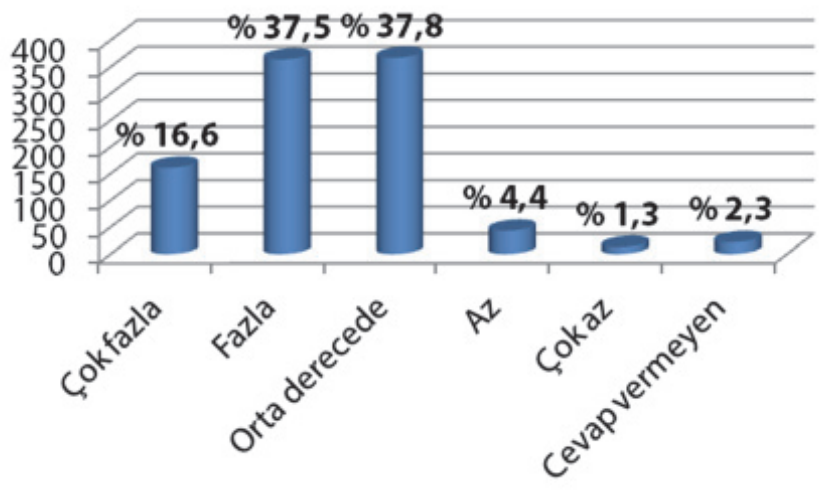

ŞEKiL 7. Farmakoekonomi bilgisinin eczacılık mesleğine katkısı

Şekil 7 ve Şekil 8' de farmakoekonomi biliminin öneminin yeterince bilinip bilinmediğine ve öneminin kavranması için çalışma yapılmasının gerekliliğine yönelik olarak eczacılık öğrencilerinin görüşlerine yer verilmiştir. Bu bilgiler öğrencilerin öğrenim gördüğü okul bilgisi ile karşılaştırılmıştır.

\section{Sizceülkemizde farmakoekonomi biliminin önemi yeterince biliniyor mu?}

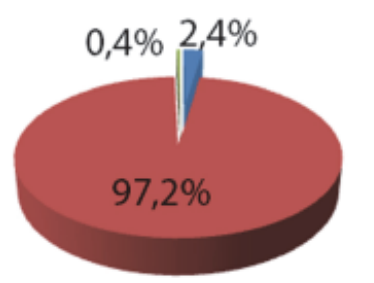

\author{
Evet \\ - Hayır \\ - Cevap vermeyen
}

ŞEKiL 8. Farmakoekonomi biliminin önemi

Katılımcıların \%97,2'si farmakoekonomi biliminin öneminin bilinmediğini, \%91,9'u ise öneminin kavranması için çalışmalar yapılması gerektiğini belirtmiştir. Öğrencilerin öğrenim gördüğü üniversite bilgisi ile farmakoekonomi biliminin öneminin yeterince bilinip bilinmediği ile ilgili soruya verilen yanıtlar Ki-kare testi ile sınanmış ve istatistiksel olarak anlamlı bir fark olduğu bulunmuştur $(p<0,05)$. Öğrencilerin öğrenim gördüğü üniversite bilgisi ile farmakoekonomi biliminin öneminin kavranması için çalışmalar yapılıp yapılmaması ile ilgili soruya verilen yanıtlar da Ki-kare testi ile sınanmış ve istatistiksel olarak anlamlı bir fark olmadığı bulunmuştur ( $p>0,05)$. Sonuç olarak, farmakoekonomi biliminin öneminin kavranmasına yönelik çalışma gerekliliği ile ilgili soruya verilen cevaplar değerlendirildiğinde; fakülteler arası homojen bir dağılım olduğu söylenebilir.

Öğrencilerin farmakoekonomi alanında kariyer yapmayı düşünüp düşünmediklerine yönelik bilgi toplanmıştır. Bu bilgiler öğrencilerin öğrenim gördüğü okul ve mezun olunca çalışmayı düşündükleri alan ile karşılaştırılmıştır. Öğrencilerin \%17,5'i farmakoekonomi alanında kariyer yapmayı düşündüğünü belirtmiştir. Öğrencilerin öğrenim gördüğü üniversite bilgisi ile farmakoekonomi alanında kariyer yapmayı düşünmeleri hakkındaki soruya verilen cevaplar Ki-kare testi ile s1nanmış ve istatistiksel olarak anlamlı bir fark bulunmamıştır $(p>0,05)$. Ancak ilaç sektöründe kariyer yapmayı planlayan öğrencilerin "farmakoekonomi" alaınında kariyer yapma isteği de olabileceği anlaşılmaktadır.

Farmakoekonomi alanında çalışan veya bu konuda uzman birini/birilerini tanıyı tanımadıklarına yönelik bilgi toplanmış olup, katılımcıların \%18,8'i bu soruya olumlu yanıt vermiştir. Öğrencilerin öğrenim gördüğü üniversite bilgisi ile farmakoekonomi biliminin öneminin yeterince bilinip bilinmediği ile ilgili soruya verilen yanıtlar Ki-kare testi ile sınanmış ve istatistiksel olarak anlamlı bir fark olduğu bulunmuştur $(p<0,05)$. Yani öğrencilerin öğrenim gördükleri üniversiteye göre farmakoekonomi alanında çalışan veya bu konuda uzman birini/ birilerini tanımaları durumu arasında anlamlı bir farklılı̆̆ın olmadiğı düşünülebilir.

Tablo 2' deki veriler 1şığında, "Farmakoekonomi alanında kariyer yapmayı düşünür müsünüz?" sorusu ile “Farmakoekonomi alanında çalışan veya bu konuda uzman birini/birilerini tanıyor musunuz?" sorusu karşılaştırılmıştır. Farmakoekonomi alanında kariyer yapmayı düşünen öğrencilerin \%29,0'u, bu alanında kariyer yapmayı düşünmeyen öğrencilerin ise $\% 16,7^{\prime}$ si bu konuda uzman birini/birilerini tanıdığını belirtmiştir. Her iki grupta gözlenen farklılıkların istatistiksel açıdan önemli 
olup olmadığı Ki-kare testi ile sınanmış ve istatistiksel olarak anlamlı bir fark olduğu bulunmuştur $(p<0,05)$. Sonuç olarak, farmakoekonomi alanında çalışan veya bu konuda uzman birini/birilerini tanıyan öğrencilerin bu alanda kariyer yapmayı düşünme isteklerinin benzer olduğu söylenebilir.

TABLO 2. Farmakoekonomi alanında çalışma talebi

\begin{tabular}{|c|c|c|c|c|c|c|}
\hline & \multirow[t]{3}{*}{ Gruplar } & \multicolumn{4}{|c|}{$\begin{array}{l}\text { Farmakoekonomi alanında } \\
\text { çalışan veya bu konuda uzman } \\
\text { birini/birilerini tanıyor musunuz? }\end{array}$} & \multirow{3}{*}{$\frac{\begin{array}{c}\mathbf{P} \\
\text { değeri }\end{array}}{0,000^{*}}$} \\
\hline & & \multicolumn{2}{|c|}{ Evet } & \multicolumn{2}{|c|}{ Hayır } & \\
\hline & & $\mathbf{n}$ & $\%$ & $\mathbf{n}$ & $\%$ & \\
\hline $\begin{array}{l}\text { Farmakoekonomi } \\
\text { alanında kariyer }\end{array}$ & Evet & 49 & 29,0 & 120 & 71,0 & \\
\hline $\begin{array}{l}\text { yapmayı düşünür } \\
\text { müsünüz? }\end{array}$ & Hayır & 131 & 16,7 & 652 & 83,3 & \\
\hline
\end{tabular}

Tablo 3' de farmakoekonomi alanında uzmanlaşan birinin hangi alanda çalışabileceğine yönelik olarak eczacılık öğrencilerinin görüşlerine yer verilmiştir. Farmakoekonomi alanında uzmanlaşan biri ağırlıklı olarak ilaç sektöründe olmak üzere, akademide, kamuda ve serbest danışmanlık alanında faaliyet gösterebilir. Bununla paralel olarak da öğrencilerin \%69,8'i bu alanda uzmanlaşan kişilerin ilaç sektöründe çalışabileceğini belirtmişlerdir.

TABLO 3. Farmakoekonomi alanında uzmanlaşan kişilerin çalışma alanı

\begin{tabular}{lcccc}
\hline & \multicolumn{4}{c}{$\begin{array}{c}\text { Farmakoekonomi alanında uzmanlaşan biri sizce } \\
\text { hangi alanda çalışabilir? (n) }\end{array}$} \\
\hline & $\begin{array}{c}\text { İlaç } \\
\text { sektörü }\end{array}$ & Akademi & Kamu & $\begin{array}{c}\text { Serbest } \\
\text { danışmanlık }\end{array}$ \\
\hline İstanbul Üniv. & 160 & 67 & 70 & 66 \\
Marmara Üniv. & 182 & 85 & 88 & 57 \\
Yeditepe Üniv. & 79 & 58 & 43 & 39 \\
Ankara Üniv. & 148 & 74 & 70 & 72 \\
Gazi Üniv. & 141 & 82 & 66 & 63
\end{tabular}

\section{Farmakoekonomi konusuna olan ilgiyi nasıl değerlendirirsiniz?}

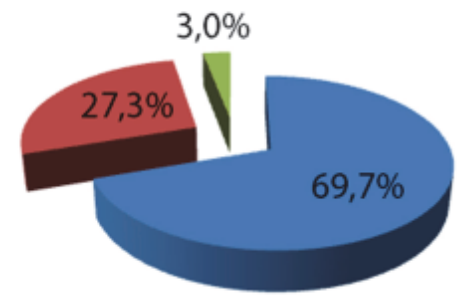

\section{Kalıcıdır \\ - Geçicidir \\ Cevap vermeyen}

ŞEKiL 9. Farmakoekonomi konusuna olan ilgi

Farmakoekonomi konusuna olan ilgiyi nasıl değerlendirdiklerine yönelik olarak eczacılık öğrencilerinin görüşlerine yer verilmiş olup, katılımcıların \%69,7'si ilgiyi "kalıcıdır" şeklinde değerlendirmiştir. Farmakoekonomi konusuna olan ilgiye yönelik soruya verilen cevaplar değerlendirildiğinde; fakülteler arası homojen bir dağılım olduğu söylenebilir.

\section{Daha önceden ISPOR'u hiç duydunuz mu?}

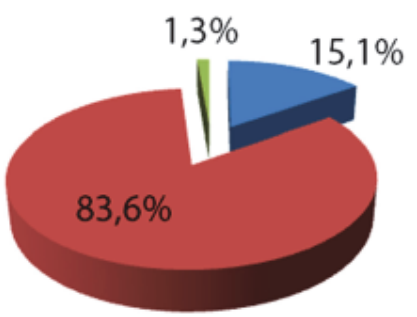

Evet

- Hayır

Cevap vermeyen

ŞEKiL 10. Eczacılık öğrencilerinin ISPOR ile İlgili farkındalıkları

Şekil 10' da eczacılık öğrencilerinin daha önceden ISPOR'u duyup duymadıkları sorgulanmıştır. Bu soruya, öğrencilerin \%15,1'inin "Evet", \%83,6'sının ise "Hayır" yanitı verdiği görülmüştür. Öğrencilerin öğrenim gördüğü üniversite bilgisi ile ISPOR hakkındaki farkındalıkları ile ilgili soruya soruya verilen cevaplar Ki-kare testi ile sınanmış ve istatistiksel olarak anlamlı bir fark bulunmuştur $(\mathrm{p}<0,05)$. Farklılığın üniversite müfredatı dışında farmakoekonomi konusunda eğitim/seminer/kurs/konferansa katılan öğrencilerden kayanaklandığ söylenebilir.

TABLO 4. Eczacılık Öğrencilerinin ISPOR'a Yönelik Fikirleri

\begin{tabular}{|c|c|c|c|c|c|c|}
\hline & \multirow[t]{3}{*}{ Gruplar } & \multicolumn{4}{|c|}{$\begin{array}{l}\text { Daha önceden ISPOR'u } \\
\text { hiç duydunuz mu? }\end{array}$} & \multirow{3}{*}{$\begin{array}{c}\mathbf{P} \\
\text { değeri } \\
0,000^{*}\end{array}$} \\
\hline & & \multicolumn{2}{|c|}{ Evet } & \multicolumn{2}{|c|}{ Hayır } & \\
\hline & & $\mathbf{n}$ & $\%$ & $\mathbf{n}$ & $\%$ & \\
\hline $\begin{array}{l}\text { Üniversite müfredatı dışında } \\
\text { farmakoekonomi konusunda } \\
\text { herhangi bir eğitim/seminer/ }\end{array}$ & Evet & 24 & 36,9 & 41 & 63,1 & \\
\hline
\end{tabular}

\section{TARTIŞMA VE SONUÇ}

Farmakoekonomi; hekimler, eczacilar, ekonomistler, farmakologlar, epidemiyologlar, sosyologlar, psikologlar gibi farklı bilim dallarından kişilerin bir araya gelmesi ile takım olarak icra edilebilecek çok yönlü bir bilim dalıdır. Bununla beraber farmakoekonomik disiplin dünya çapında ilaç endüstrisi, akademi, ilaçla ilgilenen bilim adamları ve eczacılar tarafından sağlık bilim disiplinine adapte edilmektedir (9). Eczacıların; hasta bakımında, hastaların sağlık statülerinde ve hasta bakım dağıtım sistemlerinin sağlanmasında farmasötiklerin klinik ve ekonomik etkisini değerlendirebilmeleri gerekmektedir (9). Tedavi maliyetlerini minimize etmek ve hasta yaşam kalitesini arttırmak üzere ödeyici kurum ve kuruluşlara yardımcı olmak, yani günlük pratiklerinde farmakoekonomiyi uygulamak durumundadirlar.

Yeni disiplinlerin giderek önem kazandığı sağlık bilimlerinde gerek mezuniyet öncesi gerekse sonrası eğitim programlarında farmakoekonomi derslerinin yer almasının tedavinin niteliğinin artmasına önemli katkılar sağlayacağı kuşkusuzdur (16).

Çalışmanın yapıldı̆̆ı eczacılık fakültelerinin Dekan/Dekan Yardımcısı veya bir ögretim görevlisinden toplanan bilgiler 1şığında farmakoekonomi dersinin zorunlu veya seçmeli olarak Gazi Üniversitesi ve Yeditepe Üniversitesi Eczacılık 
Fakülteleri'nde müfredatta yer aldığı görülmüştür. Ankara Üniversitesi, Marmara Üniversitesi ve İstanbul Üniversitesi Eczacılık Fakülteleri'nde ise bu konunun müfredatta yer almadığı ancak müfredata eklenmesinin düşünüldüğü belirtilmiştir. Farmakoekonominin müfredattaki yeri hakkında öğretim görevlilerinden ve öğrencilerden toplanan veriler karşılaştırıldı ̆̆ında, tüm fakültelerde öğretim görevlileri ile öğrencilerin bu soruya verdikleri yanttların tutarlı olduğu gözlenmiştir.

EPSA tarafından yapılan ve Avrupa' daki eczacılık öğrencilerinin farmakoekonomi hakkındaki bilgi düzeylerini ölçen bir anket çalışması, farkındalığın müfredat ile bağlantılı olduğunu göstermiştir. Eğitim programinda farmakoekonomi konusunun yer aldığı okullardaki öğrencilerin çoğunluğunun konu hakkında bilgi sahibi iken, müfredatta yer almadığı okullardaki öğrencilerin çoğunluğunun konu hakkında bilgi sahibi olmadiğ 1 tespit edilmiştir (11).

Türkiye' deki tıp fakültelerinde farmakoekonomi eğitiminin değerlendirildiği anket çalışmasında ise farmakoekonomi eğitimi müfredatta yer almayan fakülteler, farmakoekonomi derslerinin gelecekte öğretim programına alınacağını, bunun da çoğunlukla 1-4 saat olmak üzere ve bağımsız ayrı bir ders olarak ya da klinik farmakoloji ders ya da stajlarının içinde, 4., 5. ya da 6. öğretim yılında anlatılmasının planlandığını bildirmişlerdir (1). Günümüzün sağlık profesyonellerinin, ilaçların etkililik ve güvenlilik profillerinin yanı sıra farmakoekonomik profillerini de değerlendirmeyi göz önünde bulundurmaları gerekmektedir. Bu sebeple, Eczacılık ve Tip Fakültesi yönetimlerinin farmakoekonomi konusunu müfredatlarına ekleme planları sağlık profesyonellerinin bu alandaki etkililiklerini arttırmaya yönelik bir adım olarak düşünülebilir.

EPSA'nın Avrupa eczacılık öğrencilerine uyguladığ1 ankette; öğrencilerin yaklaşık \%60'1 farmakoekonomi eğitiminin müfredatlarında 1-7 saat arası yer aldığını belirtmişlerdir (11). Yapılan bir diğer çalışmada da Amerika dışındaki dünya ülkelerinde farmakoekonomi eğitiminin eczacılık lisans eğitiminde müfredatta ortalama 48,5 saat, lisans sonrası eğitimde ise ortalama 22,6 saat yer aldı̆̆ı vurgulanmıştır (12). Amerika'daki eczacılık fakültelerinde yapılan bir çalışmada da farmakoekonomi eğitiminin zorunlu olarak müfredatta ortalama 21 saat, seçmeli olarak ise ortalama 31 saat yer aldığı belirtilmiştir (14). Türkiye'ye baktığımızda, diğer ülkelerle kıyaslandığında eczacılık fakültelerinde verilen farmakoekonomi eğitiminin müfredatta yeterli yoğunlukta yer almadığı söylenebilir.

Ülkemizde sağlık alanında faaliyet gösteren aşağıdaki kurum ve dernekler bünyesinde farmakoekonomi alanında eczacı ve hekimler rol almaktadir:

- T.C. Sağlık Bakanlığı Türkiye İlaç ve Tıbbi Cihaz Kurumu (TİTCK) bünyesindeki "Akılcı İlaç Kullanımı Birimi", "Fiyat Birimi" ve "Sağlık Teknolojileri Değerlendirme Birimi"

- Sosyal Güvenlik Kurumu (SGK) bünyesinde yer alan "Geri Ödeme Komisyonu", "Tibbi ve Ekonomik Değerlendirme Komisyonu”, “Teknik Komisyon”
- Türk Eczacıları Birliği (TEB) Farmakoekonomi Farmakoepidemiyoloji Farmakovijilans (3F) Araştırma Merkezi

- Araştırmacı İlaç Firmaları Derneği (AIFD) bünyesindeki "Fiyatlandırma Komitesi" ve "Geri Ödeme Komitesi"

- IIlaç Endüstrisi İşverenleri Sendikası (İEİS) bünyesinde yer alan "İlaç Politikaları ve Araştırma Birimi”, "Fiyat ve Geri Ödeme Komisyonu"

Bu veriler 1şığında ülkemizde farmakoekonomi alanında yetişmiş uzmana günümüzde olduğu gibi gelecekte de ihtiyaç duyulacağını anlaşılmaktadır.

Eğitim sistemini yönlendiren ve biçimlendiren en önemli öğelerden ilk üçü “öğrenci”, “eğitici» ve «eğitim programları»dır. Eğitimin etkili, verimli ve kaliteli olabilmesi, nitelikli insan gücünün yetiştirilmesi, bu öğeler arasındaki ilişkinin sağlıklı ve uyumlu olmasına bağlıdır.

Eğitim denince, konunun ana kısminda yer alan taraflardan biri olan Üniversitelere önemli görevler düşmektedir. Üniversitelerin öncelikle araştırıcıların ilgisini çekecek temel yöntemsel başlıkları geliştirmeleri gerekmektedir. Bu gerçekleştiği takdirde bilimsel anlamda önemli adımların atılması olasıdır. Araştırmacıların değişik uygulamalar sonucu alacakları bu kavramları sanayinin gereksinimlerine uygulamaları sonucunda da etkili sonuçların alınması ve çok yönlü yararların sağlanabileceği kesindir (17). Farmakoekonomi son yıllarda giderek daha fazla önem kazandığından; özellikle farmakoekonomik araştırmaların gerçekleştirilebilmesi için günümüzde yetişmiş insan gereksinimi oldukça fazla olup, bu ihtiyacın kısa sürede tamamlanması zorunludur.

Tüm dünyada sağlık harcamalarının artması ile ilaç harcamaları kontrol altına alınmaya çalışılmaktadır. Özellikle kronik hastalıkların artması ile ilaç kullanım süreleri uzamakta, buna bağlı olarak geri ödeme yapan kurumların bütçe hassasiyeti artmaktadır. Önümüzdeki dönemde fiyatlandırma yaklaşımının değişmesi ve farmakoekonomik değerlendirmenin öneminin artmaktadır (18). Bu durumun da ilaç sektöründe farmakoekonomi konusunda uzman kişi ihtiyacını arttırması beklenebilir.

Sonuç olarak dünyanın değişik yörelerinde yapılan çalışmalara karşın, ülkemizdeki üniversitelerin farmakoekonomi politikaları hususunda kendinden beklenen rolü henüz gerçekleştiremediği, bu nedenle yoğun ileri çalışmalara gereksinim olduğu açıktır.

Eczacılar ilaç tüketimi üzerine yakın bir bakış açısına sahip olduklarından ve rasyonel ilaç kullanımını destekleyebileceklerinden; hem üretim hem de klinik ilaç maliyetlerini azaltabilirler. Farmakoekonomi hastaların yaşam kalitesini arttırmada önemli bir hedef olduğu için; eczacıların bu alandaki aktivitelerini arttırmak üzere aksiyonlar alınması gerekmektedir. Bunun için eczacılık fakültelerinin müfredatlarına farmakoekonomi dersinin eklenmesi, ardından bu alanda eğitimli uzman sayısını arttırmak amacıyla yüksek lisans ve doktora programlarının ivedilikle açılması gereklidir. 


\section{Pharmacoeconomics education and the knowledge levels of pharmacy students a in schools of pharmacy}

\section{ABSTRACT}

PURPOSE: The purpose of this study is to review the pharmacoeconomics education in the schools of pharmacy and to determine the knowledge levels of students on pharmacoeconomics. The study aims to reveal the place of pharmacoeconomics subject in pharmacy education programs and the compare the importance and the status of the subject in Turkey.

METHOD: In this study, relating with the purpose, survey method has been used to determine knowledge levels of 4th and 5th grade students in scools of pharmacy, in Istanbul and Ankara, on pharmacoeconomics. The survey questions have been prepared by the researchers.

RESULTS: It is understood that pharmacoeconomics cource is currently been offered in two faculties' curriculum, and it is being planned to include it in other schools' curriculum, too. When the results of the surveys are assessed, it has been observed that the students of the faculties, whose educational curriculum includes pharmacoeconomics, has more knowledge on the subject. It has also been found that $78 \%$ of the students, are willing to have education on pharmacoeconomics.

CONCLUSION: 970 students, from five schools of pharmacy, have participated in the survey. It is necessary to add the pharmacoeconomics education into the curriculums. It should be considered that in Turkey, pharmacoeconomics knowledge needs to be included in the curriculum of undergraduate, graduate and post- graduate programs in order to increase the number of educated experts in this area.

KEY WORDS: Pharmacoeconomics, Health economics, Education, Pharmacy, Pharmacy education

\section{KAYNAKLAR}

1. Gülmez SE, Tulunay FC, Ergun $H$. Türkiye' deki tıp fakültelerinde farmakoekonomi eğitimi. Genel Tıp Dergisi 2009; 19;2.

2. Kobelt G. Sağlık Ekonomisi: Ekonomik Değerlendirmeye Giriş. (2nd ed.) OHE, Londra, 2002.

3. Townsend RJ. Post-marketing drug research and development: an industry clinical pharmacists' perspective. Am J Pharm Educ 1986; 50:480-2.

4. Doherty J, Kamae I, Lee KC. What is next for pharmacoeconomics and outcomes research in Asia? Value Health 2004; 7: 118-3.

5. Bootman JL, Wertheimer AI, Zaske D, Rowland C. Individualizing gentamicin dosage regimens on burn patients with gram-negative septicemia: a cost-benefit analysis. J Pharm Sciences 1979; 68: 267-72.

6. Çiftçi M. Türkiye'de eczacılık fakültelerindeki öğrencilerin öğretim üyelerinden sağladıkları sosyal fayda düzeylerinin atkinson eşitsizlik endeksi yaklaşımıyla ölçümü. Hacettepe Üniversitesi Eczacılık Fakültesi Dergisi 2009; 29:45-59.

7. Rascati KL, Drummond MF, Annemans L, Davey PG. Education in pharmacoeconomics: an international multidisciplinary view (Review). Pharmaco-Economics 2004; 22:139-47.

8. Jana E. Pharmacoeconomics: The need to sensitize undergraduate medical students. Indian J Pharmacol 2005; 37: 277-8.

9. Yeğenoğlu S, Emre H. Farmakoekonomi alanında temel kavramlar. Ankara Ecz Fak Derg 2004; 33:41-61.
10. Sanchez LA. Expanding the role of pharmacists in pharmacoeconomics. Why and how? Pharmacoeconomics 1994; 5:367-75.

11. Gafa M, Bilbija S, Martinova A, Bates I. Pharmacoeconomics: A view of epsa member countries on 1ssues related to awareness of the topic and the undergraduate curriculum. Pharmacy Education 2002; 2:171-5.

12. Nwokeji ED, Rascati KL. Pharmacoeconomic education in colleges of pharmacy outside of the United States. Am J Pharm Educ 2005; 69:52.

13. Rascati KL, Conner TM, Draugalis JR. Pharmacoeconomic education in U.S. schools of pharmacy. Am J Pharm Educ 1998; 62:167-9.

14. Reddy M, Rascati K, Wahawisan J, Rascati M. Pharmacoeconomic education in US colleges and schools of pharmacy: An Update. Am J Pharm Educ 2008; 72:51.

15. Sümbüloğlu K, Sümbüloğlu V. Biyoistatistik (6rd ed.) Ankara: Özdemir M 1995; 156-157.

16. Eroğlu L. Farmakoekonomi: Genel bakış. ANKEM Dergisi 1996; 10:302-4.

17. Breimer DD: Future training needs in the pharmaceutical sciences: Academia-Industry. Eur J Pharm Sci 2001; 12:347-52.

18. Araştırmacı İlaç Firmaları Derneği. Türkiye İlaç Sektörü Vizyon 2023 Raporu. s.: 29, Ağustos 2012. 